\title{
Contribution of Metabolic Syndrome in Controlling Diabetes Mellitus According to Gender in Indonesia (RISKESDAS 2018)
}

\author{
Julianty Pradono ${ }^{1}$, Delima ${ }^{2}$, Nunik Kusumawardani ${ }^{1}$, Frans Dany $^{3}$ \& Yudi Kristanto ${ }^{1}$ \\ ${ }^{1}$ Centre for Research and Development of Public Health Efforts, National Institute of Health Research and \\ Development, Indonesia Ministry of Health, Indonesia \\ ${ }^{2}$ Centre for Research and Development of Health Resources and Services, National Institute of Health Research \\ and Development, Indonesia Ministry of Health, Indonesia \\ ${ }^{3}$ Centre for Research and Development of Biomedical and Basic Health Technology, National Institute of Health \\ Research and Development, Indonesia Ministry of Health, Indonesia
}

Correspondence: National Institute of Health and Research Development of Indonesia Jl. Percetakan Negara 29 Jakarta 10560. Indonesia. Tel: 62-021-425-9860, Fax: 62-021- 424-4375.

Received: September 2, 2020, Accepted: November 2, 2020. Online Published: November 20, 2020

doi:10.5539/gjhs.v13n1p46 URL: https://doi.org/10.5539/gjhs.v13n1p46

\begin{abstract}
Background: Metabolic syndrome (MetS) is a multiple risk factor for the development of type 2 diabetes mellitus (DM). It is important to understand the contribution of MetS in developing DM in different population characteristics. This study aims to obtain the prevalence of MetS and the magnitude of the contribution of MetS risk factors as a basis for developing targeted DM intervention programs.
\end{abstract}

Methods: This study used data from the 2018 Riskesdas survey, an Indonesia national health survey, with a total sample of 24,545 individuals aged 15 years and over. This study selected only respondents who had never been diagnosed with diabetes mellitus before the survey was conducted and have complete MetS data according to the National Cholesterol Education Program or Adult Treatment Panel III (NCEP/ATP III) criteria. Data had been analyzed for the Population Attributable Fraction (PAF) statistical test.

Results: A total of 29.2 percents of the population with MetS and the prevalence in women (17.2\%) was higher than in men $(11.9 \%)$ Three components of MetS that contribute greatly to DM were fasting blood glucose levels, hypertension and high triglyceride levels. If the men population can maintain two risk factors (fasting blood sugar levels and blood pressure) under normal conditions, the prevalence of DM can be reduced by as much as 15 percent. In women, if three factors (fasting blood sugar levels, blood pressure, and triglyceride levels) can be maintained under normal conditions, the prevalence of DM can be reduced by 29.9 percent.

Conclusion: Prevention strategy of DM need to include monitoring and controlling of the metabolic syndrome and behavioral risk factors, that can be applied in primary health center as well as in community-based setting of health program.

Keywords: metabolic syndrome, population attributable fraction

\section{Background}

Metabolic syndrome (MetS) is a multiple risk factor arising from insulin resistance, accompanied by abnormal fat deposition and function. It is a combination of risk factors for type 2 diabetes mellitus, coronary heart disease, fatty liver, chronic kidney disorders, and several types of cancer (Kaur, 2014; S. Stanley, 2018). Metabolic syndrome has become a public health problem and is a clinical challenge throughout the world. Although MetS is not a disease, early detection will give a very meaningful to be overcome immediately (Magdalena, 2014). Metabolic syndrome is related to urbanization, excessive energy intake, increased incidence of obesity, and a sedentary lifestyle and is related to the effects it causes. It is estimated that in the next 5 to 10 years there will be a threefold increase in the risk of DM and two-fold cardiovascular disease. Respondents with metabolic syndrome have a risk of stroke two to four times and the risk of myocardial infarction three to four times.

The metabolic prevalence of the syndrome based on the Framingham Study cohort study in the 26-82 years age group was 29.4 percent in men and 23.1 percent in women (Khanna et al., 2013). Whereas in Europe 15 percent 
(Elabbassi \& Haddad, 2005), in South Korea 14.2 percent (Park et al., 2004). While in Indonesia as much as 23.34 percent of the total population (Suhaema \& Masthalina, 2015).

There are 9 global targets for controlling non-communicable diseases (NCD) by 2025, among others, there is no increase in the prevalence of diabetes mellitus or obesity, a reduction in deaths from NCD (heart disease, cancer, diabetes, and chronic lung disease) until 2025, and a decrease in high blood pressure as much as 25 percent by 2025 (PAHO/WHO, 2015; WHO, 2013).

In Indonesia, the government has tried to control DM by focusing on control through (1) strengthening the management of DM according to standards in first-level health facilities (FKTP); (2) accelerated discovery of NCD risk factors through "NCD health post (Posbindu PTM)"; (3) accelerated early discovery of potentially DM cases; (4) increased monitoring of the success of DM treatment with $\mathrm{HbAlc}$; (5) strengthening interventions for the magnitude of metabolic syndrome, modification of NCD risk behaviors through Posbindu PTM (Ministry of Health, 2015). While the study of the relationship between sex and the prevalence contribution of the MetS component has never been based on a national basis.

Based on the above problems, further analysis of the National Health Survey 2018 aimed to obtain the prevalence of metabolic syndrome and the magnitude of the contribution of MetS risk factors as a basis for developing targeted DM intervention programs in the development of health strategies to manage MetS according to gender in preventing the occurrence of DM.

\section{Conceptual Framework}

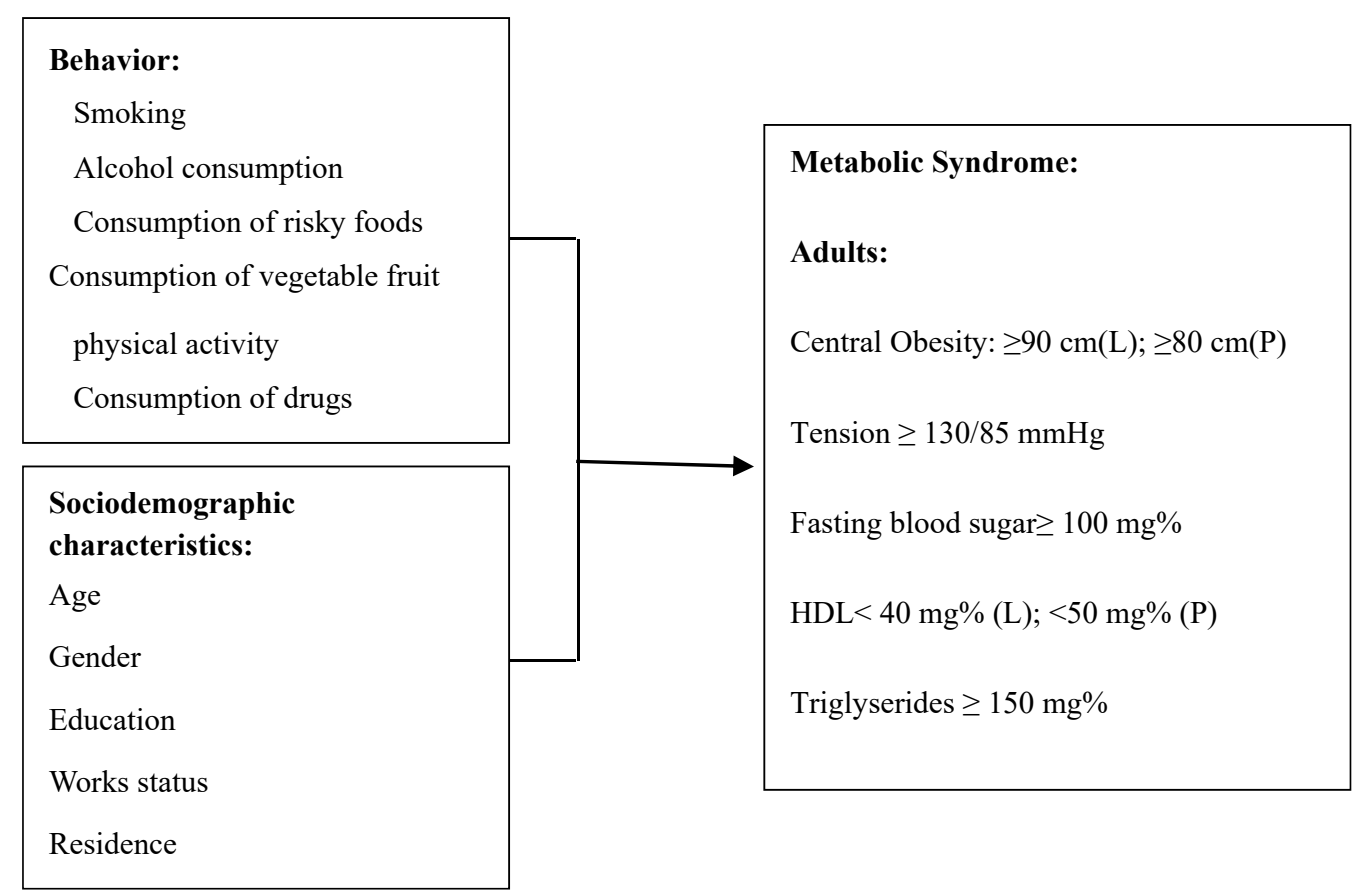

Figure 1. The conceptual framework of diabetes mellitus

\section{Methods}

This study uses the 2018 Riskesdas data, with a total population target of the age group of 15 years and over. The sample of the analysis were respondents who had never been diagnosed with diabetes mellitus before the survey was conducted. Respondents have complete SM data according to the National Cholesterol Education Program or Adult Treatment Panel III (NCEP / ATP III) (Cleeman, 2001). The criteria were modified in 2004 and adapted for Asians. According to the modified NCEP-ATP III criteria, the definition of MetS consists of clinical conditions of at least 3 or more than 5 risk factors, namely central obesity (abdominal circumference $>90 \mathrm{~cm}$ for men and $>80 \mathrm{~cm}$ for women), low cholesterol HDL (men $<40 \mathrm{mg} \%$ and women $<50 \mathrm{mg}$, or currently under treatment), high serum triglycerides $(\geq 150 \mathrm{mg} \%$, or currently under treatment), increased blood pressure $(\geq$ $130 / 85 \mathrm{mmHg}$ or currently under treatment), and fasting blood glucose ( $\geq 100 \mathrm{mg} \%$ or currently under treatment). Whereas in adolescents which include 5 indicators namely central obesity 90 percent of adult criteria 
(abdominal circumference $\geq 81 \mathrm{~cm}$ in men or $\geq 72 \mathrm{~cm}$ in women); triglyceride levels $\geq 110 \mathrm{mg} \%$; HDL levels $>$ $40 \mathrm{mg} \%$ in men or $>40 \mathrm{mg} \%$ in women; systolic blood pressure $\geq 117 \mathrm{mmHg}$ ( $90 \%$ of adult criteria) and diastolic blood pressure $\geq 77 \mathrm{mmHg}$ (90\% of adult criteria); and fasting blood sugar level $\geq 100 \mathrm{mg} \%$. The definition of metabolic syndrome is based on the presence of 3 of the 5 indicators (Nolan et al., 2017). (Table 1)

The unit of analysis is the Individual aged $\geq 15$ years, and taking into account the age groups of teenagers (15-24 years) and adults ( $\geq 25$ years) in men and women. The types of analysis are descriptive, bivariate, multivariate, and Population Attributable Fraction (PAF) analysis (Gerstman, 2014).

Table 1. Criteria for metabolic syndrome for adult Asians according to NCEP's ATP III

\begin{tabular}{lll}
\hline Criteria & Adult & adolescents \\
\hline Triglycerides $\mathrm{mg}^{2} \%$ & $\geq 150$ & $\geq 110$ \\
HDL $\mathrm{mg} \%$ & & \\
Men & $<40 \mathrm{mg}$ & $\leq 40$ \\
Women & $<50 \mathrm{mg}$ & $\leq 40$ \\
Abdominal circumference & & \\
Men & $\geq 90 \mathrm{~cm}$ & $\geq 81(90 \%)$ \\
Women & $\geq 80 \mathrm{~cm}$ & $\geq 72(90 \%)$ \\
Fasting Blood Glucose $\mathrm{mg} \%$ & $\geq 100$ & $\geq 100$ \\
Blood pressure mmHg & $\geq 130 / 85$ & $\geq 117 / 77(90 \%)$ \\
\hline
\end{tabular}

Source: Cook, S et al. 2003. (Cook et al., 2003).

\subsection{Data Analysis}

The analysis will be differentiated based on groups of men and women. Data analysis was performed descriptively to obtain data on the characteristics of respondents who had never been diagnosed with diabetes mellitus before the survey. Bivariate analysis used cross-tabulation with $95 \% \mathrm{CI}$ and $\mathrm{p}$-value $(\mathrm{p}<0.05)$ to obtain the prevalence of MetS and each component of risk factors in MetS. The analysis continued by focusing on respondents with diabetes mellitus (DM) based on the NCEP ATP III criteria. Multivariate analysis was performed to obtain risk factors from the MetS component that had a contribution to DM. As independent variables include demographic characteristics (age, education, occupation, residence, economic status) and behavior (physical activity, smoking based on the Brinkman index, consumption of vegetable fruits, mental-emotional disorders, and BMI).

After determining the determinant factors that have a relationship with DM in each group, the analysis continues with Population Attributable Fraction (PAF) calculation to get the contribution of each variable that can contribute to reducing the prevalence of DM.

\subsection{Ethical Approval}

Ethical approval for the study was obtained from the human ethics committee, National Institute of Health and Research Development of Indonesia, with number LB.02.01/3/KE.024/2018.

\section{Results}

Respondents in this analysis were 24,545 people, among them 50.5 percent of men $(n=12,392)$, slightly higher than 49.5 percent of women $(n=12,153)$. 


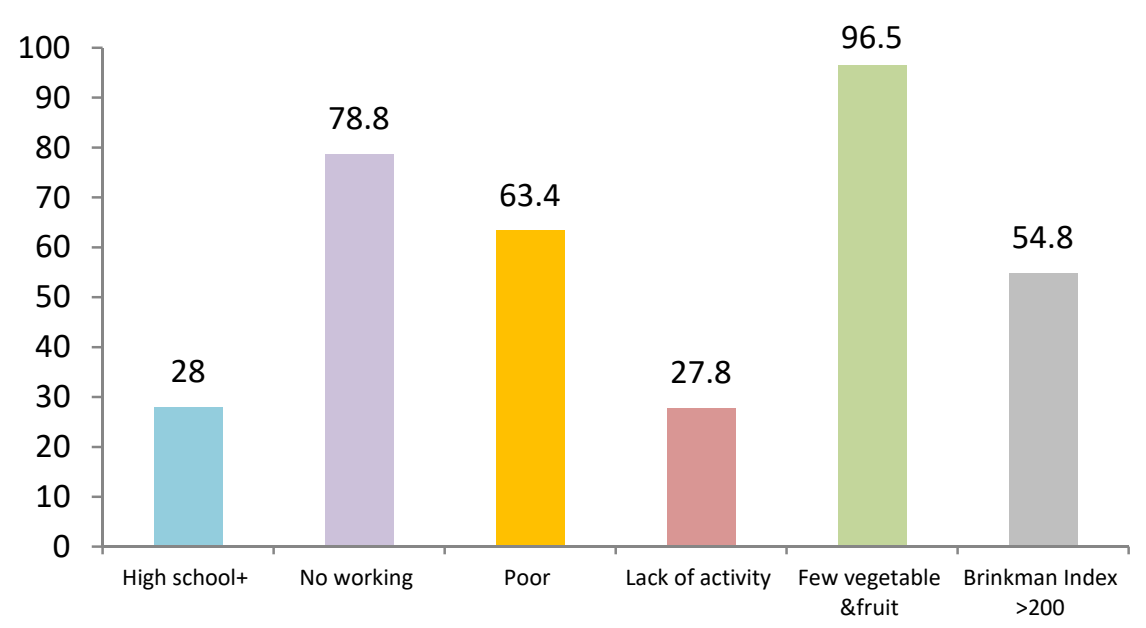

Figure 2. Graph of sociodemography and behavior of respondents who have never been diagnosed with diabetes by health workers, Riskesdas 2018

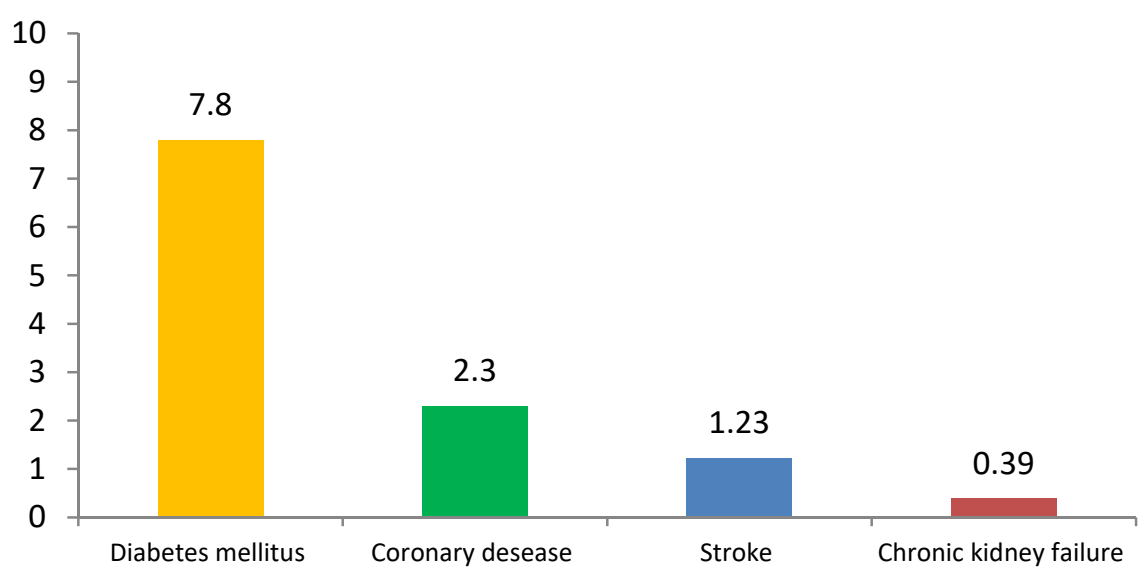

Figure 3. Graph of comorbid respondents who have never been diagnosed with diabetes by health workers, Riskesdas 2018

The mean age of respondents was 43.1 years, in men with slightly older age than women, more with high school education or more, less physical activity, more than one-half the smokers with a Brinkman index $>200$ cigarettes (Figure 2), and more at risk of stroke than women. The mean body mass index, abdominal circumference, blood pressure both systolic and diastolic, lipid profile, and fasting blood sugar are still not at risk.

Women respondents with an average age of 42.3 years, most $(90.1 \%$ ) did not work, more suffer from DM and heart disease than men. The average body mass index is classified as overweight $\left(24 \mathrm{~kg} / \mathrm{m}^{2}\right)$, abdominal circumference $(80.6 \mathrm{~cm})$, and fasting blood sugar levels $(100.1 \mathrm{mg} \%)$ are close to risky.

Table 2 shows the characteristic description of those who have never been diagnosed of having diabetes mellitus in population aged 15 years and above. 
Table 2. Description of respondents who have never been diagnosed with diabetes by health workers, in the age group of 15 years and over, Riskesdas 2018

\begin{tabular}{|c|c|c|c|}
\hline & $\begin{array}{l}\text { All } \\
\mathrm{N}=\mathbf{2 4 . 5 4 6}\end{array}$ & $\begin{array}{l}\text { Men }(49,2 \%) \\
n=12.393\end{array}$ & $\begin{array}{l}\text { Women }(50,8 \%) \\
n=12.153\end{array}$ \\
\hline Average age (years) & $43,1 \pm 15,7$ & $43,9 \pm 16,0$ & $42,3 \pm 15,2$ \\
\hline High school+ \% & $28,0(27,4-28,5)$ & $30,1(29,7-31,4)$ & $25,9(24,8-26,1)$ \\
\hline No working $\%$ & $78,8(78,5-80,0)$ & $55,5(53,8-57,3)$ & $90,1(89,8-90,9)$ \\
\hline Poor \% & $63,4(62,2-63)$, & $62,7(61,2-63,1)$ & $64,1(62,9-64,5)$ \\
\hline Lack of activity $\%$ & $27,8(26,9-27,9)$ & $31,2(29,9-31,8)$ & $24,2(23,4-24,7)$ \\
\hline Few vegetable \& fruit $\%$ & $96,5(96,1-96,8)$ & $96,4(89,9-96,6)$ & $96,5(96,1-96,7)$ \\
\hline Brinkman Index >200 (\%) & $54,8(53,0-55,6)$ & $54,9(54,0-56,7)$ & $22,7(19,6-29,9)$ \\
\hline Diabetes mellitus \% & $7,8(7,3-9,6)$ & $5,9(5,4-6,5)$ & $9,7(8,8-10,9)$ \\
\hline Coronary desease $\%$ & $2,3(2,1-2,5)$ & $2,0(1,8-2,3)$ & $2,5(2,3-2,7)$ \\
\hline Stroke $\%$ & $1,23(1,1-1,4)$ & $1,4(1,2-1,6)$ & $1,08(0,93-1,25)$ \\
\hline Chronic kidney failure $\%$ & $0,39[0,32-0,47]$ & $0,4(0,3-0,6)$ & $0,37(0,29-0,47)$ \\
\hline Average IMT $\left(\mathrm{Kg} / \mathrm{m}^{2}\right)$ & $23,7 \pm 4,7$ & $22,6 \pm 4,1$ & $24,0 \pm 4,9$ \\
\hline Average abdominal circumference $(\mathrm{cm})$ & $79,6 \pm 11,9$ & $78,7 \pm 11,6$ & $80,6 \pm 12,2$ \\
\hline Average systolic mmHg & $130,9 \pm 23,5$ & $130,4 \pm 21,3$ & $131,4 \pm 25,6$ \\
\hline Average diastolic $\mathrm{mmHg}$ & $84,0 \pm 12,7$ & $82,9 \pm 12,2$ & $85,2 \pm 13,2$ \\
\hline Average total cholesterol mg \% & $179,0 \pm 39,2$ & $173,7 \pm 38,5$ & $184,5 \pm 39,2$ \\
\hline Average HDL mg\% & $47,3 \pm 11,1$ & $43,9 \pm 9,9$ & $50,7 \pm 11,3$ \\
\hline Average triglyceride $\mathrm{mg} \%$ & $129,8 \pm 90,9$ & $142,3 \pm 101,1$ & $117,1 \pm 76,9$ \\
\hline Average fasting blood glucose $\mathrm{mg} \%$ & $99,3 \pm 2,6$ & $98,5 \pm 19,8$ & $100,1 \pm 29,5$ \\
\hline
\end{tabular}

\subsection{Metabolic Syndrome and its Components}

In Indonesia, the prevalence of metabolic syndrome in the population aged 15 years and over, who has never been diagnosed with DM before the survey is 29.2 percent (95\% CI, 28.6-29.8). (See table 3) The prevalence among men is 11.9 percent $(95 \% \mathrm{CI}, 11.5-12.4)$ and in women is 17.2 percent $(95 \% \mathrm{CI}, 16.8-17.7)$. In urban areas is 15.2 percent $(95 \% \mathrm{CI}, 14.7-15.7)$ is higher than in rural areas 13.9 percent (95\% CI, 13.5-14.4). Population with lower economic status and low education ( $\leq$ junior high school education) have a higher prevalence of metabolic syndrome than higher economic and education status. Metabolic syndrome is higher among those who have sufficient physical activity, which is 21.6 percent $(95 \% \mathrm{CI}, 21.0-22.2)$ than those with less physical activity 7.6 percent $(7.2-7.9)(\mathrm{P}=0.0002)$. 
Table 3. The prevalence of metabolic syndrome and its components according to characteristics and DM

\begin{tabular}{|c|c|c|c|c|c|c|c|}
\hline & & Central obesity & $\begin{array}{l}\text { High fasting } \\
\text { Blood glucose }\end{array}$ & Hypertension & $\begin{array}{l}\text { High } \\
\text { Trigliserida }\end{array}$ & Low HDL & $\begin{array}{l}\text { Metabolic } \\
\text { Syndrom }\end{array}$ \\
\hline \multirow{2}{*}{ Ages } & $45+\mathrm{yrs}$ & $16.6(16.4-17.4)$ & $19.8(19.2-20.5)$ & $29.9(29.3-30.6)$ & $14.7(14.2-15.2)$ & $17.1(16.6-17.6)$ & $16.4(15.9-16.9)$ \\
\hline & $\begin{array}{c}15-44 \\
\text { yrs }\end{array}$ & $17.3(16.8-17.8)$ & $11.9(11.4-12.5)$ & $20.9(20.3-21.4)$ & $12.5(12.0-12.9)$ & $24.2(23.6-24.8)$ & $12.8(12.4-13.3)$ \\
\hline \multirow{2}{*}{ Gender } & Men & $8.5(8.1-8.9)$ & $14.4(13.8-15.0)$ & $24.3(23.8-25.1)$ & $16.4(15.8-16.9)$ & $17.3(16.7-17.9)$ & $11.9(11.5-12.4)$ \\
\hline & Women & $25.7(25.1-26.3)$ & $17.3(16.8-17.9)$ & $26.4(25.8-26.9)$ & $10.8(10.4-11.2)$ & $23.9(23.4-24.5)$ & $17.2(16.8-17.7)$ \\
\hline \multirow{2}{*}{ Education } & $\begin{array}{c}\leq \text { junior } \\
\text { high } \\
\text { school }\end{array}$ & $23.4(22.9-24.0)$ & $24.4(23.7-25.2)$ & $38.4(37.7-39.0)$ & $19.4(18.9-19.9)$ & $29.7(29.1-30.1)$ & $21.5(21.0-22.1)$ \\
\hline & $\begin{array}{l}\geq \text { high } \\
\text { school }\end{array}$ & $10.8(10.3-11.2)$ & 7.3(6.8-7.7) & $12.5(12.0-12.9)$ & $7.7(7.4-8.1)$ & $11.5(11.1-11.9)$ & $7.7(7.3-8.1)$ \\
\hline \multirow[t]{2}{*}{ Jobs } & $\begin{array}{l}\text { Not } \\
\text { work }\end{array}$ & $33.4(32.4-34.3)$ & $23.8(22.8-24.8)$ & $38.9(38.0-39.9)$ & $17.1(16.3-17.8)$ & $35.9(34.9-36.9)$ & $23.3(22.5-24.2)$ \\
\hline & Work & 7.3(6.8-7.9) & $5.2(4.7-5.9)$ & $9.6(8.9-10.3)$ & $6.9(6.4-7.5)$ & $8.3(7.8-8.9)$ & $6.1(5.6-6.6)$ \\
\hline \multirow{2}{*}{ Areas } & Urban & $21.6(20.9-22.1)$ & $15.6(14.9-16.2)$ & $27.4(26.8-28.1)$ & $15.3(14.8-15.9)$ & $22.2(21.6-22.8)$ & $15.2(14.7-15.7)$ \\
\hline & Rural & $12.7(12.2-13.1)$ & $16.2(15.6-16.8)$ & $23.4(22.8-23.9)$ & $11.8(11.4-12.3)$ & 19.1(18.6-19.6) & $13.9(13.5-14.4)$ \\
\hline \multirow{2}{*}{ Welfare } & Poor & $18.2(17.7-18.8)$ & $20.4(19.7-21.1)$ & $32.2(31.6-32.9)$ & $16.5(15.9-17.1)$ & $25.7(25.0-26.3)$ & $17.8(17.2-18.3)$ \\
\hline & Enough & $14.8(14.3-15.3)$ & $11.8(11.2-12.4)$ & $18.8(18.2-19.4)$ & $11.5(11.0-12.0)$ & $14.8(14.3-15.4)$ & $11.4(10.9-11.9)$ \\
\hline \multirow{2}{*}{$\begin{array}{l}\text { Brinkman } \\
\text { Index }\end{array}$} & $\begin{array}{l}\leq 200 \\
\text { sticks }\end{array}$ & $6.8(6.1-7.5)$ & $12.5(11.2-13.8)$ & $18.6(17.5-19.8)$ & $13.9(12.9-14.9)$ & $17.5(16.4-18.6)$ & $9.5(8.7-10.3)$ \\
\hline & $\begin{array}{l}>200 \\
\text { sticks }\end{array}$ & $9.2(8.4-10.1)$ & 20.4(18.9-21.9) & $27.3(26.1-28.6)$ & $20.5(19.4-21.7)$ & $20.8(19.7-22.0)$ & $14.0(13.1-15.0)$ \\
\hline \multirow{2}{*}{$\begin{array}{l}\text { Physical } \\
\text { activity }\end{array}$} & Less & $8.8(8.4-9.2)$ & $8.4(7.9-8.9)$ & $13.8(13.3-14.3)$ & $7.8(7.4-8.2)$ & $11.6(11.1-12.0)$ & 7.6(7.2-7.9) \\
\hline & Enough & $25.4(24.8-26.0)$ & $23.3(22.6-24.0)$ & $37.0(36.4-37.7)$ & $19.4(18.8-19.9)$ & $29.7(29.1-30.3)$ & $21.6(21.0-22.2)$ \\
\hline \multirow{2}{*}{$\begin{array}{l}\text { Vegetable } \\
\text { fruit } \\
\text { portions }\end{array}$} & Less & $32.8(32.1-33.4)$ & $30.3(29.5-31.1)$ & $49.0(48.3-49.7)$ & $26.1(25.4-26.7)$ & $39.7(39.0-40.4)$ & $27.9(27.4-28.6)$ \\
\hline & Enough & $1.4(1.3-1.6)$ & $1.4(1.2-1.6)$ & $1.8(1.6-1.9)$ & $1.1(0.1-1.3)$ & $39.7(39.0-40.4)$ & $1.2(1.1-1.4)$ \\
\hline \multirow{2}{*}{$\begin{array}{l}\text { Diabetes } \\
\text { mellitus }\end{array}$} & Yes & $3.8(3.6-4.1)$ & $8.7(8.3-9.2)$ & $5.3(5.0-5.6)$ & $2.8(2.6-3.1)$ & $3.7(3.4-3.9)$ & $5.6(5.3-5.9)$ \\
\hline & No & $30.4(29.7-31.0)$ & $22.9(22.3-23.7)$ & $45.5(44.8-46.2)$ & $24.3(23.7-24.9)$ & $37.6(36.9-38.2)$ & $23.6(23.0-24.2)$ \\
\hline Total & & $34.2(33.5-34.9)$ & $31.7(30.9-32.5)$ & $52.0(51.4-52.6)$ & $27.2(26.6-27.8)$ & $41.3(40.6-41.9)$ & $29.2(28.6-29.8)$ \\
\hline
\end{tabular}

\subsection{Determinants Factors of Metabolic Syndrome in Diabetes Mellitus According to Gender}

Table 4 shows multivariate analysis result of the relationship between MetS and DM after controlled by other factors, such as socio-demographic, health risk behaviors, nutrition status, blood lipid profile, and glucose. According to the magnitude of MetS risk factors, there appear to be differences between men and women the incidence of DM. In men, the risk factors that have a relationship with DM are fasting blood glucose levels > $100 \mathrm{mg} \%$ and hypertension, while the other 3 factors do not show a significant relationship. Whereas in women, the five MetS risk factors have a relationship with DM. Based on the order of strong relationships are fasting blood glucose levels $>100 \mathrm{mg} \%$, hypertriglyceridemia, hypertension, central obesity, and low HDL levels. Overall the 3 main factors of metabolic syndrome which play a major role in DM are high fasting blood sugar, hypertension, and hypertriglyceridemia. (Tabel 4) 
Table 4. The Relationship of Metabolic Syndrome Risk Factors and Diabetes mellitus in the age group 15 years and over, according to gender

\begin{tabular}{|c|c|c|c|c|c|c|c|c|c|c|c|c|c|}
\hline & & \multicolumn{4}{|l|}{ Men } & \multicolumn{4}{|c|}{ Women } & \multicolumn{4}{|l|}{ All } \\
\hline & & ajOR & Lower & Upper & $\mathrm{p}$ & ajOR & Lower & Upper & $\mathrm{p}$ & ajOR & Lower & Upper & $\mathrm{p}$ \\
\hline Ages group & & 2,5 & 2,0 & 3,2 & 0,00 & 1,6 & 1,4 & 1,9 & 0,00 & 1,9 & 1,7 & 2,1 & 0,00 \\
\hline Hypertension & & 1,4 & 1,1 & 1,7 & 0,00 & 1,5 & 1,3 & 1,7 & 0,00 & 1,4 & 1,3 & 1,6 & 0,00 \\
\hline Central obesity & & 1,2 & 0,9 & 1,5 & 0,17 & 1,2 & 1,1 & 1,4 & 0,01 & 1,4 & 1,2 & 1,5 & 0,00 \\
\hline Low HDL & & 1,2 & 1,0 & 1,5 & 0,12 & 1,2 & 1,0 & 1,3 & 0,04 & 1,2 & 1,1 & 1,4 & 0,00 \\
\hline $\begin{array}{l}\text { Triglyserides } \\
\mathrm{mg} \%\end{array}$ & $>150$ & 1,2 & 0,9 & 1,5 & 0,18 & 1,8 & 1,5 & 2,0 & 0,00 & 1,4 & 1,2 & 1,5 & 0,00 \\
\hline FBG $>100 \mathrm{mg} \%$ & & 6,3 & 5,1 & 7,8 & 0,00 & 5,9 & 5,1 & 6,8 & 0,00 & 5,9 & 5,3 & 6,7 & 0,00 \\
\hline
\end{tabular}

Note. ajOR $=$ adjusted Odd Ratio.

\subsection{Contribution of Metabolic Syndrome Components to Diabetes Mellitus}

In general, three of the five components of metabolic syndrome have a major contribution, including high fasting blood glucose levels, high triglyceride levels, and hypertension. (Table 5)

If the three components can be maintained in normal conditions, the prevalence of DM can decrease from 7.8 percent to 6.0 percent, this indicates a decrease in DM prevalence of 23 percent. This shows as many as $3,392,152$ people will be free of DM from 14,748,486 people who were suffering.

In men aged 15 years and over, the risk factors for MetS that contribute to DM are high fasting blood glucose contributing about 0.71 percent and hypertension about 0.06 percent. If all men respondents with DM can reduce FBG to $\leq 100 \mathrm{mg} \%$, then the prevalence of DM will decrease from 5.9 percent to 5.2 percent. Among males, those who had DM and maintained the blood pressure level to $\leq 130 / 85 \mathrm{mmHg}$ then the prevalence of DM can be reduced to 5.8 percent. If these two factors (fasting blood sugar levels and blood pressure) can be maintained normally, the prevalence of DM can be reduced from 5.9 percent to 5.0 percent. This shows the prevalence of DM in men can be reduced by 15 percent, so as many as 856,327 men can free from DM.

For women aged 15 years and over, the risk factors for MetS that contribute to DM are high fasting blood glucose contributing 1.5 percent, hypertriglyceridemia levels 0.5 percent, and hypertension 0.2 percent. If all women respondents with DM could decrease FBG $\leq 100 \mathrm{mg} \%$, then the prevalence of DM could change from 9.7 percent to 8.2 percent. If women DM respondents can maintain triglycerides $<150 \mathrm{mg} \%$ then the prevalence of women DM can be reduced to 9.2 percent, while women DM respondents can maintain blood pressure $\leq$ $130 / 85 \mathrm{mmHg}$ then the prevalence of DM can decrease from 9,7 percent to 9,5 percent. If these three factors (fasting blood sugar, blood pressure, and triglyceride levels) can be maintained at a normal level, the prevalence of DM can decrease by 29.9 percent. It means the prevalence of DM can decrease from 9.7 percent to 6.8 percent, which is as many as $2,714,289$ women can avoid DM.

Table 5. The contribution of MetS risk factors to DM by gender

\begin{tabular}{|c|c|c|c|c|c|c|c|c|c|}
\hline \multirow{3}{*}{ Risk factors } & \multicolumn{3}{|c|}{ Prev. DM men } & \multicolumn{3}{|c|}{ Prev. DM Women } & \multicolumn{3}{|c|}{ Prev. DM all } \\
\hline & \multicolumn{3}{|c|}{$5,9 \%$} & \multicolumn{3}{|c|}{$9,7 \%$} & \multicolumn{3}{|c|}{$7,8 \%$} \\
\hline & PAF & $\begin{array}{l}\text { Contrib } \\
\text { ution }\end{array}$ & $\begin{array}{l}\text { DM } \\
\text { proporsi } \\
\text { on tobe }\end{array}$ & PAF & $\begin{array}{l}\text { Contrib } \\
\text { ution }\end{array}$ & $\begin{array}{l}\text { DM } \\
\text { propors } \\
\text { ion tobe }\end{array}$ & PAF & $\begin{array}{l}\text { Contribu } \\
\text { tion }\end{array}$ & $\begin{array}{l}\text { DM } \\
\text { proportio } \\
\text { n tobe }\end{array}$ \\
\hline $\mathrm{FBG} \geq 100 \mathrm{mg} \%$ & 0,12 & 0,708 & 5,2 & 0,153 & 1,484 & 8,2 & 0,138 & 1,076 & 6,7 \\
\hline Central obesity & - & - & - & 0,013 & 0,126 & 9,6 & 0,019 & 0,148 & 7,7 \\
\hline Low HDL & - & - & - & 0,01 & 0,097 & 9,6 & 0,012 & 0,094 & 7,7 \\
\hline $\begin{array}{l}\text { Triglyceride } \\
\geq 150 \mathrm{mg} \%\end{array}$ & - & - & - & 0,049 & 0,475 & 9,2 & 0,024 & 0,187 & 7,6 \\
\hline
\end{tabular}




\begin{tabular}{cccccccccc}
\hline Hypertension & 0,011 & 0,065 & 5,8 & 0,018 & 0,175 & 9,5 & 0,015 & 0,117 & 7,7 \\
FBG+Hyperten & 0,145 & 0,855 & 5,0 & 0,191 & 1,853 & 7,8 & 0,171 & 1,334 & 6,5 \\
FBG+ Triglyser & - & - & - & 0,251 & 2,435 & 7,3 & 0,188 & 1,466 & 6,3 \\
$\begin{array}{c}\text { Hypert+Triglyser } \\
\text { ide }\end{array}$ & - & - & - & 0,073 & 0,708 & 9,0 & 0,039 & 0,304 & 7,5 \\
$\begin{array}{c}\text { FBG+ Triglyser } \\
+ \text { Hypertensi }\end{array}$ & - & - & - & 0,298 & 2,8906 & 6,8 & 0,225 & 1,755 & 6,0 \\
\hline
\end{tabular}

\section{Discussion}

This study found that the prevalence of MetS was 29.2 percent (estimated 25,431,537 people) among the population aged 15 years or older who has never been diagnosed with DM by a healthcare provider. This prevalence increased compared to the results in 2013 (23.3\%) (Suhaema \& Masthalina, 2015), even though in 2013 it was reported in all age groups of 15 years or better who had been diagnosed or who had never been diagnosed with diabetes by health workers. Nearly one in 3 population, with an estimated 55,212,283 population aged 15 years and over were having MetS. The International Diabetes Federation (IDF) estimates that about 25 percent of the world's population suffers from MetS, in that estimation, there are variations in age, ethnicity, and gender of the population. (Nolan et al., 2017) Cohort data in Isfahan, Iran after 7 years of follow-up indicate that incidents of MetS were 27 percent with an incidence rate of 39.2 per 1000 person-years in men and 46.6 per 1000 person-years in women $(\mathrm{p}=0.04)$ (Franklin \& Wong, 2013). Compared to the results in Iran, the incidence of $\mathrm{BC}$ in Bogor is still low, this is related to different eating patterns between respondents in Iran and Bogor. Some research results in Asia show that the prevalence of metabolic syndrome is between 35.8 percent to 45.3 percent in India, 30.5 percent to 31.5 percent in China, and 16.5 percent in Malaysia (Harikrishnan et al., 2018).

The relationship between sex and the prevalence of MetS and its components among Indonesian adults shows that gender appears to be an independent predictor of the prevalence of most MetS components. The high prevalence of MetS and its components occurs mainly in women, in urban areas, respondents with low income (poor), and low education ( $\leq$ junior high school), except that the hypertriglyceridemia variable is found to be higher in men. Differences in the prevalence of MetS components may be related to gender characteristics (eg, biological traits and functional features) and gender-related determinants (eg, psychological and cultural habits) (PERKENI, 2015). Changes in hormone levels during and after menopause can contribute to gender differences in the prevalence of the MetS component in older populations (Sarah, 2004). There is an increase in metabolic syndrome in the younger age group due to lifestyle changes. Nevertheless, it is very important to obtain the prevalence of metabolic syndrome in the age group of 15 years or more because the presence of metabolic syndrome components can lead to an increased risk of developing diabetes mellitus and heart disease (Kaur, 2014).

This study shows the mean systolic blood pressure (SBP) and diastolic blood pressure (DBP) is relatively high, while. the average for women is higher than for men. The Framingham Heart Study shows that DBP is a better predictor for future chronic disease events than SBP in adults $<50$ years; The truth has been proven after the age of 50 years that the underlying chronic disease is isolated diastolic hypertension (Franklin \& Wong, 2013). There are observed differences between rural and urban respondents. This has been proven in several other studies relating to a more sedentary lifestyle in city dwellers (Harikrishnan et al., 2018). Gender disparities in blood pressure are believed to be due to differences in biological and behavioral factors including hormonal differences, higher prevalence of obesity, higher mean fasting blood sugar levels, and other determinants such as not working, residential areas. Similar risk factors have also been reported in other studies (Suhaema \& Masthalina, 2015).

In Riskesdas 2018, the prevalence of diabetes mellitus in respondents who had never been diagnosed with diabetes by health workers was 7.8 percent (5.9\% in men and $9.7 \%$ in women). Diabetes mellitus (DM) is a chronic disease due to impaired carbohydrate metabolism due to a progressive decline in pancreatic beta-cell function resulting in insulin resistance (PERKENI, 2015). The incidence of DM continues to increase both in developed and developing countries due to lifestyle changes. The number of people with DM in Indonesia ranks fourth in the world after India, China, and America. (Sarah, 2004) This is in line with the findings of the noncommunicable disease risk factors cohort study in Bogor City. This study found that the incidence of MetS in 2018 was 6.8 percent or 19.2 per 1,000 person-years. The cumulative incidence for 6 years in MetS was 151 
people, with a hazard rate of 9 per mile (Ministry of Health Republic of Indonesia, 2018). It means that the increasing prevalence of DM in Indonesia is due to the increasing number of MetS occurring in the community. Diabetes mellitus as a cause of disability has increased in 27 years, from the ninth position in 1990 to the fourth position in 2017 (WHO, 2017).

Harikrishnan found that MetS respondents who suffer from DM amounted to 15.6 percent in India (Harikrishnan et al., 2018). Although the results in Indonesia were not as large as in India, vigilance against the risk of DM in MetS respondents needed special attention.

An impaired fasting glucose level is a state of prediabetes. In this study the mean fasting blood glucose levels in women were $100.1 \mathrm{mg} \%$ higher than MetS criteria of WHO criteria. The prevalence of fasting glucose disturbance (IFG) in men is 14.4 percent and in women is 17.3 percent. High fasting blood glucose levels are more common in women, urban dwellers, prevalence increases with age, higher in overweight and obese individuals, and individuals with low physical activity. These results are consistent with the results of the national health survey 2013, the more age increases the risk of hyperglycemia due to decreased work of the pancreas in producing insulin. This finding is an initial intervention to stop or inhibit the development of diabetes mellitus (World Health Organization, 2016).

Dyslipidemia is a risk factor for non-communicable diseases. This study shows that, hypertriglyceridemia was 27.2 percent and low HDL cholesterol level was 41.3 percent among those with dyslipidemia. Low HDL cholesterol levels in Indonesia were higher than Mohamud's study in Malaysia (34\%) (Mohamud et al., 2011). But lower than Fernanda studies in Brazil showed a high prevalence of HDL cholesterol with low criteria (59.3\%) (Vidigal et al., 2013). Likewise in the Indian Council of Medical Research - Indian Diabetes Study (ICMR-INDIAB) reported 13.9 percent had hypercholesterolemia, 29.5 percent had hypertriglyceridemia 72.3 percent with low HDL cholesterol and 11.8 percent had LDL high. Seventy-nine (79\%) had abnormalities in one of the lipid parameters (Mohan et al., 2014).

These results are in line with previous studies which reported that dyslipidemia in people with type 2 diabetes can increase the risk of complications of other non-communicable diseases such as coronary heart disease (Nolan et al., 2017).

This study also shows, an increase in the prevalence of MetS with increasing age. Likewise, research in Malaysia shows that the prevalence of MetS tends to increase by 3 percent every year in respondent age (Mohamud et al., 2011).

In India, MetS respondents with a prevalence of central obesity were 58.6 percent (Harikrishnan et al., 2018). The Suhaema get results that the risk of central obesity in MetS respondents by 53 percent (Suhaema \& Masthalina, 2015). This result is higher than central obesity. in Indonesia which is 34.2 percent.

This situation is closely related to diet, especially carbohydrate intake from each different country. As research in Poland found evidence that traditional carbohydrate diet patterns (high intake of wheat, potatoes, sugar, and sweet foods) gave high scores and correlated the occurrence of central obesity ( $p$ trend $=0.001$ ), as well as increased triglyceride levels ( $\mathrm{p}$ trend $=0.005$ ) (Suliga et al., 2017).

According to a national health insurance and social security agency in Indonesia (BPJS) report, the amount of funding for DM is estimated to reach 20 trillion rupiahs in 2018. Meanwhile, results of 2013 Riskesdas, showed ten percent of the population suffering from DM visited to a health facility ( Ministry of Health of the Republic Indonesia, 2013; Suliga et al., 2017). It can be estimated that a DM patient requires medical expenses of around 12,743,803 IDR (Indonesia Rupiah).

The contribution of normal blood sugar levels and blood pressure in preventing DM, implicates that around 856,327 men aged 15 years or older can be prevented from DM, consequently government can save health expenditure as much as 1.1 trillion in men and 3.5 trillion in women

\section{Conclusion}

This study shows that prevalence of MetS in populations aged 15 years and over in men and women in Indonesia remained high. Components of MetS that contribute greatly to reducing the prevalence of DM in men are high fasting blood sugar levels and hypertension. Whereas in women, MetS components that have a major contribution are fasting blood glucose levels, hypertriglyceridemia, and hypertension. Prevention efforts to reduce the prevalence of DM by considering the magnitude of the contribution of risk factors for metabolic syndrome. It can be planned to be implemented in primary health care facilities. 


\section{Acknowledgments}

We would like to thank for World Health Organization, the Riskesdas 2018 advanced analysis, data management team, and technical team, the research committee of the center for research and development of public health efforts, who have supported the implementation of further analysis. Also to Prof. dr. Meiwita Paulina Budiharsana, MPA., Ph.D., Prof. dr. Emiliana Tjitra, M.Sc, Ph.D., Dr. dr. Iwan Ariawan, MSPH., And Dr. Rina Agustina, M.Sc, Ph.D. have provided direction and guidance during further analysis activities.

\section{Competing Interests Statement}

The authors declare that there are no competing or potential conflicts of interest.

\section{References}

Cleeman, J. I. (2001). Executive summary of the third report of the National Cholesterol Education Program (NCEP) expert panel on detection, evaluation, and treatment of high blood cholesterol in adults (adult treatment panel III). Journal of the American Medical Association, 285(19), 2486-2497. https://doi.org/10.1001/jama.285.19.2486

Cook, S., Weitzman, M., Auinger, P., Nguyen, M., \& Dietz, W. H. (2003). Prevalence of a metabolic syndrome phenotype in adolescents: findings from the third National Health and Nutrition Examination Survey, 1988-1994. Archives of pediatrics \& adolescent medicine, 157(8), 821-827. https://doi.org/10.1001/archpedi.157.8.821

Elabbassi, W. N., \& Haddad, H. A. (2005). The epidemic of the metabolic syndrome. Saudi Medical Journal, 26(3), 373-375.

Franklin, S. S., \& Wong, N. D. (2013). Hypertension and cardiovascular disease: Contributions of the Framingham Heart Study, Global Heart. World Heart Federation (Geneva), 8(1), 49-57. https://doi.org/10.1016/j.gheart.2012.12.004

Gerstman, B. B. (2014). Epidemiology Kept Simple, XXXIII(2), 81-87.

Harikrishnan, S., Sarma, S., Sanjay, G., Jeemon, P., Krishnan, M. N., Venugopal, K., ... \& Zachariah, G. (2018). Prevalence of metabolic syndrome and its risk factors in Kerala, South India: Analysis of a community based cross-sectional study. PLoS One, 13(3), e0192372. https://doi.org/10.1371/journal.pone.0192372

Kaur, J. (2014). A comprehensive review on metabolic syndrome. Cardiology research and practice, 2014. https://doi.org/10.1155/2014/943162

Ministry of Health. (2015). Permenkes no.71, 2015, (1775). (In Bahasa)

Ministry of Health of Republic of Indonesia. (2013). Highlights of the Indonesian Health Survey 2013. Health Research and Development Agency. https://doi.org/10.1017/CBO9781107415324.004

Ministry of Health Republic of Indonesia. (2018). Main results 2018 national health survey report. (In Bahasa)

Khanna, R., Kapoor, A., Kumar, S., Tewari, S., Garg, N., \& Goel, P. K. (2013). Metabolic syndrome \& Framingham Risk Score: observations from a coronary angiographic study in Indian patients. The Indian Journal of Medical Research, 137(2), 295.

Magdalena. (2014). Factors related to metabolic syndrome in outpatients at ulin hospital in Banjarmasin. Health Scale, 5(2), 1-6. (In Bahasa)

Wan Mohamud, W. N., al-SafiIsmail, A., ShahIsmail, I., ImranMusa, K., Kadir, K. A., ... \& WanBebakar, W. M. (2011). Prevalence of metabolic syndrome and its risk factors in adult Malaysians: Results of a nationwide survey. Diabetes Research and Clinical Practice, 91(2), 239-245. https://doi.org/10.1016/j.diabres.2010.11.025

Shahid, A., Raman V, S., Ashok Kumar, D., India, D. C., Viswanathan, M., Siddhartha, N. S., \& Surendra Kumar, S. (2014). Current status of management, control, complications, and psychosocial aspects of patients with diabetes in India: Results from the DiabCare India 2011 Study. Indian Journal of Endocrinology and Metabolism, 18(3), 370-378. https://doi.org/10.4103/2230-8210.129715.

Nolan, P. B., Carrick-Ranson, G., Stinear, J. W., Reading, S. A., \& Dalleck, L. C. (2017). Prevalence of metabolic syndrome and metabolic syndrome components in young adults: A pooled analysis. Preventive medicine reports, 7, 211-215. https://doi.org/10.1016/j.pmedr.2017.07.004

PAHO/WHO (2015). Challenges and goals for 2025: Achieving the NCD targets in the Caribbean, WHO. 
Retrieved from

file://C:/Users/FamMD/Downloads/3--Key-messages--Panel-1-Challenges_Goals-2025_5-June-2015-(1) (3).pdf

Park, H. S., Oh, S. W., Cho, S., Choi, W. H., \& Kim, Y. S. (2004). The metabolic syndrome and associated lifestyle factors among South Korean adults. International Journal of Epidemiology, 33(2), 328-336. https://doi.org/10.1093/ije/dyh032

Indonesian Endocrinology Association (PERKENI) (2015). Consensus on management and prevention of DM type 2 in Indonesia 2015. (In Bahasa)

S.Stanley, W. (2018). Metabolic syndrome. e-medicine, 37(3), 111-112. https://doi.org/10.5414/NHP37111

Sarah, W. (2004). Estimates for the year 2000 and projections for 2030. World Health, 27(5), 1047-1053. https://doi.org/10.2337/diacare.27.5.1047

Suhaema, S., \& Masthalina, H. (2015). The consumption patterns of the prevalence of metabolic syndrome in public health. National Public Health Journal, 9(4), $340 . \quad$ (In Bahasa) https://doi.org/10.21109/kesmas.v9i4.741

Suliga, E., Kozieł, D., Ciesla, E., Rebak, D., Głuszek-Osuch, M., Naszydłowska, E., \& Głuszek, S. (2017). Dietary patterns in relation to metabolic syndrome among adults in Poland: A cross-sectional study. Nutrients, 9(12), 1-15. https://doi.org/10.3390/nu9121366

Vidigal, F. D. C., Bressan, J., Babio, N., \& Salas-Salvadó, J. (2013). Prevalence of metabolic syndrome in Brazilian adults : a systematic review.

WHO. (2013). Challenges and goals for 2025 : Achieving the NCD targets in the Caribbean Key Messages : 1. Global monitoring framework on the prevention and control of noncommunicable diseases (GMF) 2. GMF indicator data availability in the Caribbean, 1-3.

WHO. (2017). Global burden of disease study 2017. The Lancet, 1-7.

World Health Organization. (2016). Global report on Diabetes, Isbn, 978, 88.

\section{Copyrights}

Copyright for this article is retained by the author(s), with first publication rights granted to the journal.

This is an open-access article distributed under the terms and conditions of the Creative Commons Attribution license (http://creativecommons.org/licenses/by/4.0/). 